\title{
Analisis Theory of Reasoned Action serta Pengaruh Price, Location, dan Developer's Reputation Terhadap Purchase Intention pada Apartemen di Sidoarjo
}

\author{
Mega Meilya Alif \\ Universitas Airlangga \\ e-mail: megameilya@yahoo.com
}

\begin{abstract}
The purpose of this study is to analyze the theory of reasoned action and the influences of price, location and developer's reputation toward apartment purchase intention in Sidoarjo. This research uses a quantitative approach and include as clausal study. The sampling technique is non probability sampling. The criteria of the respondents are people who were born between 19802000 or the age group of 20-40 years in 2020 (millennials), who is planning to buy an apartment within the one year; and has never bought an apartment in Sidoarjo before. The techniques of data collection uses a survey method by five-level of Likert scale. The questionnaire was distributed by electronic links using email and social media. This study uses multiple linear regression assisted with the Statistical Program for Social Science (SPSS) software for the data analysis. The result of the study are attitude, subjective norms, price, location, and developer's reputation have a significance influence toward purchase intention.
\end{abstract}

Keywords: theory of reasoned action, price, location, developer's reputation, purchase intention, apartment

\section{PENDAHULUAN}

Saat ini di Sidoarjo telah bermunculan beberapa pengembang apartemen yang saling bersaing memperebutkan pasar. Melihat besarnya potensi pertumbuhan properti di Sidoarjo, persaingan di sektor tersebut menjadi semakin ketat. Untuk bertahan di pasar yang kompetitif, para developer harus mengingat bahwa apartemen merupakan high-involvement product dan memerlukan pengambilan keputusan yang matang. Artinya, apartemen merupakan jenis barang yang tidak sering dibeli, berharga mahal, dan memiliki risiko tinggi. Oleh karena itu, perusahaan harus mampu menyediakan informasi sebanyak mungkin kepada konsumen mengenai produk yang mereka tawarkan. Bagi sebagian orang, membeli apartemen adalah salah satu keputusan ekonomi paling signifikan dan memerlukan pengumpulan banyak informasi mengenai fitur, kualitas, fasi- litas, desain, harga, lokasi, dan lingkungan (Nursal dkk., 2019:697).

Pada tahun 2019 umumnya harga minimal perumahan di Sidoarjo ditawarkan dengan harga di atas 500 juta rupiah dengan lokasi di wilayah perkotaan, sedangkan apartemen ditawarkan dengan harga antara 300-900 juta rupiah (Jawapos, 2019). Adanya pengembangan pembangunan apartemen secara tidak langsung meningkatkan harga saham bagi perusahaan property (Karya et al., 2018). Saat ini terdapat tiga pengembang apartemen yang bersaing di Sidoarjo yaitu Apartemen Tamansari Prospero, Suncity Residence Apartemen, dan Shafira City Apartemen. Lokasi ketiganya berada di pusat kota dengan kemudahan akses jalan utama, transportasi, dan berbagai fasilitas umum lainnya. Penghuni apartemen juga dimanjakan dengan kepraktisan melalui banyaknya fasilitas apartemen seperti kolam renang, 
pusat kebugaran, café, restaurant, dan pusat perbelanjaan yang dapat menunjang gaya hidup mereka.

Keberhasilan pemasaran apartemen tergantung pada analisis yang benar atas perilaku pembelian konsumen. Untuk mengetahui tentang kebutuhan konsumen, maka pemasar harus memahami faktor atau variabel apa yang secara signifikan memengaruhi niat pembelian apartemen. Penting bagi para pemasar untuk menganalisis niat pembelian konsumen sebagai upaya untuk memengaruhi, memastikan kepuasan, dan pengembangan bisnis yang berkelanjutan. Niat pembelian atau purchase intention adalah kecenderungan dan hasrat yang secara kuat mendorong individu untuk membeli suatu produk. Menurut Wu dan Teng (2011:7585) niat pembelian dapat dipahami sebagai suatu perencanaan untuk membeli produk atau layanan tertentu di masa depan.

Niat pembelian pada konsumen, menurut Theory of Reasoned Action (TRA) milik Fishbein dan Ajzen (1980), dapat diprediksi oleh dua variabel yaitu sikap (attitude) dan norma subjektif (subjective norms). Attitude didefinisikan sebagai cara individu merespons dan/atau kecenderungan individu terhadap suatu objek. Selain itu, attitude juga terbukti memiliki pengaruh yang signifikan terhadap intention (Yusliza \& Ramayah, 2011:491). Hasil penelitian Al-Nahdi (2014:39) menunjukkan bahwa sikap memiliki pengaruh positif terhadap niat pembelian konsumen pada apartemen di Saudi Arabia.

Sedangkan subjective norms merupakan hasil dari bagaimana seseorang merasakan tekanan yang diberikan oleh orang lain untuk melakukan atau tidak melakukan suatu perilaku (Ajzen dan Fishbein, 1980). Bisa jadi tekanan tersebut berasal dari kelompok referensi, keluarga, rekan kerja, teman dekat, atau bahkan influencer. Ter- dapat temuan penelitian yang meyatakan bahwa pasangan dan anak memiliki pengaruh yang signifikan terhadap niat pembelian sebuah hunian. Anak-anak memiliki peran yang paling berpengaruh dalam memprediksi niat pembelian hunian diikuti oleh pasangan, orang tua, dan terakhir teman (Sangkakoon, dkk., 2014:6).

Berdasarkan penjabaran tersebut, penulis melihat pentingnya attitude dan subjective norms untuk digunakan sebagai prediktor niat beli apartemen di Sidoarjo. Selain itu, mengingat Sidoarjo adalah daerah penyangga Kota Surabaya, faktor lainnya seperti harga (price), lokasi (location), dan reputasi developer (developer's reputation) juga dapat menjadi sesuatu yang dipertimbangkan konsumen dan memengaruhi niat beli mereka. Temuan penelitian milik Nasar dan Manoj (2014:8) bahwa price, location dan developer's reputation ada di peringkat lima besar dari sepuluh faktor paling signifikan yang menentukan keputusan pembelian apartemen. Ajzen (1991) dalam Chia, dkk. (2016:97) mengungkapkan bahwa niat pembelian dan keputusan pembelian berada pada dua tahap yang berbeda dalam teori perilaku konsumen, namun ada hubungan yang signifikan antara kedua tahap ini, terutama dalam kaitannya dengan pembelian hunian.

Bagi milenial yang berada di usia awal bekerja, tingginya harga rumah tapak tidak menutup kemungkinan jika sebagian dari mereka lebih memilih apartemen sebagai hunian tempat tinggal. Selain dapat memenuhi gaya hidup praktis mereka, harga yang ditawarkan juga lebih terjangkau apabila dibandingkan dengan rumah tapak. Hal tersebut menggambarkan bahwa harga dapat menjadi salah satu faktor yang memengaruhi niat pembelian konsumen. Oleh karena tingkat harga merupakan pertimbangan utama bagi konsumen selama proses pembelian aparte- 
men (Nasar \& Manoj, 2014:9). Studi serupa oleh Razak, dkk. (2013) mengonfirmasi bahwa pertimbangan finansial khususnya harga rumah memiliki pengaruh yang sangat kuat terhadap niat pembelian.

Selain harga, lokasi apartemen juga menjadi faktor yang memengaruhi niat beli konsumen. Lokasi berkaitan erat dengan jarak dari berbagai tempat yang menarik seperti dekat dengan pusat bisnis, sekolah, tempat bekerja dan pusat perbelanjaan (Chia, dkk., 2016:97). Studi sebelumnya menemukan bahwa lokasi dianggap sebagai pertimbangan penting bagi pembeli rumah (Razak, dkk., 2013). Sebagian konsumen memiliki preferensi masing-masing dalam menentukan lokasi hunian/apartemen yang diinginkan. Wang dan Li (2004) dalam Al-Nahdi (2014:35) menjelaskan bahwa di Cina, sebagian konsumen menghindari lokasi apartemen yang dekat dengan beberapa fasilitas umum yang ramai namun lebih memilih untuk lebih dekat dengan sekolah atau taman. Sementara itu, beberapa penelitian lainnya menyatakan bahwa memilih hunian di Saudi Arabia juga dapat dipengaruhi oleh lokasinya yang dekat dengan sekolah dan keluarga (Opoku \& AbdulMuhmin, 2010:223).

Reputasi developer juga merupakan faktor yang dapat memengaruhi niat beli konsumen. Semakin tinggi reputasi yang dimiliki oleh suatu developer maka kecenderungan niat beli konsumen juga akan tinggi. Namun, karena adanya kekhawatiran sebagian konsumen akan proyek apartemen yang gagal dan tidak diselesaikan tepat waktu yang sebagian besar disebabkan oleh pengembang, peran reputasi developer menjadi semakin penting dalam pemilihan apartemen. Nursal, dkk. (2019:700) menyatakan bahwa repuatsi developer menjadi perhatian banyak konsumen sebab pengembang apartemen yang jelas menurunkan kekhawatiran konsumen me- ngenai banyaknya masalah seperti penipuan atau proyek pembangunan apartemen yang macet.

Oleh karena itu, berangkat dari theory of reasoned action serta melihat latar belakang pada penelitian ini, penulis bermaksud untuk menganalisis lebih jauh mengenai pengaruh attitude, subjective norms, price, location, dan developer's reputation terhadap purchase intention apartemen di Sidoarjo. Dengan demikian, nantinya penelitian ini diharapkan dapat bermanfaat dan menjadi masukan bagi para pengembang properti di Sidoarjo dalam membuat perencanaan pemasaran apartemen dengan memahami niat pembelian konsumen.

\section{KERANGKA KONSEPTUAL}

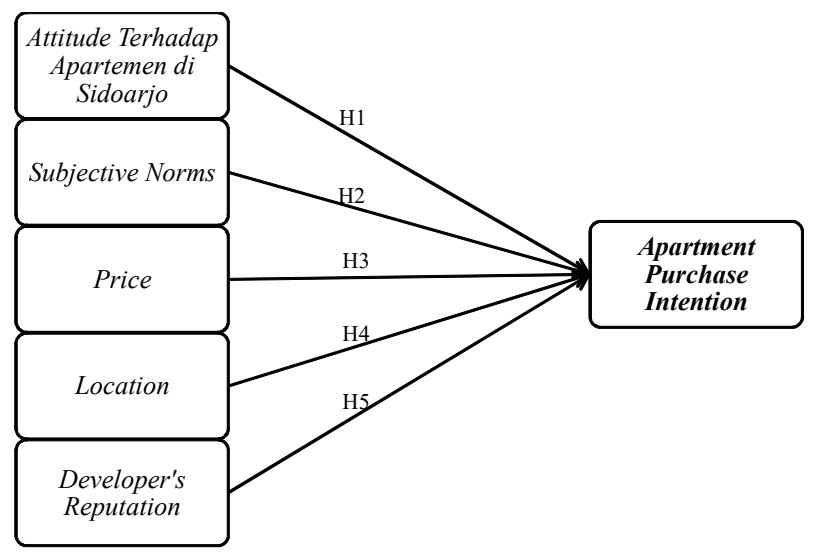

\section{METODE PENELITIAN}

Pendekatan yang digunakan pada penelitian ini merupakan pendekatan kuantitatif. Penelitian ini termasuk dalam kategori penelitian studi klausal atau sebab akibat. Berdasarkan sumbernya, penelitian ini menggunakan data primer. Populasi penelitian ini adalah masyarakat atau orang-orang yang berencana untuk membeli properti. Sampel penelitian ini adalah orang-orang yang termasuk dalam kelompok milenial (generasi-y) yang lahir antara tahun 1980-2000 atau 
kelompok umur 20-40 tahun pada tahun 2020; berencana untuk membeli apartemen dalam kurun waktu satu tahun ke depan; dan belum pernah membeli apartemen di wilayah Sidoarjo. Teknik pengumpulan data melalui survei dengan kuesioner yang menggunakan skala likert lima tingkat. Kuesioner tersebut disebarkan melalui tautan elektronik dengan menggunakan email dan media sosial. Teknik analisis yang digunakan adalah regresi linier berganda yang dibantu dengan software Statistic Program for Social Science (SPSS).

\section{HASIL PENELITIAN}

Kuesioner penelitian disebarkan kepada masyarakat dengan golongan umur 21-40 tahun, yang berencana untuk membeli apartemen dalam kurun waktu satu tahun ke depan, dan belum pernah membeli apartemen di Sidoarjo sebelumnya. Dari 347 data responden yang terkumpul, sebanyak 244 yang memenuhi kriteria penelitian. Responden kelompok usia antara 21-25 tahun adalah sebanyak 27 orang dengan persentase sebesar 11,1\%. Jumlah responden dengan kelompok usia antara 26-30 tahun adalah sebanyak 182 orang dengan persentase sebesar $74,6 \%$. Jumlah responden dengan kelompok usia antara 31-35 tahun adalah sebanyak 29 orang dengan persentase sebesar 11,9\%. Jumlah responden dengan kelompok usia antara 35-40 tahun adalah sebanyak enam orang dengan persentase sebesar $2,5 \%$.

Jumlah responden dengan status lajang/ belum menikah adalah sebanyak 115 orang dengan persentase sebesar 47,1\%. Selanjutnya, responden dengan status menikah adalah sebanyak 129 orang dengan persentase sebesar $52,9 \%$. Jumlah responden yang berdomisili di Kota Surabaya adalah sebanyak 91 orang dengan persentase sebesar $37,3 \%$. Selanjutnya, responden yang berdomisili di Kabupaten Sidoarjo adalah sebanyak 76 orang dengan persentase sebesar 31,1\%. Terakhir, responden dengan domisili lainnya (selain Surabaya dan Sidoarjo) adalah sebanyak 77 orang dengan persentase sebesar 31,6\%.

Jumlah responden dengan pendidikan terakhir tingkat SLTA adalah sebanyak 21 orang dengan persentase sebesar 8,6\%. Responden dengan pendidikan terakhir tingkat Diploma (D3) adalah sebanyak 23 orang dengan persentase sebesar 9,4\%. Sementara responden dengan pendidikan terakhir tingkat sarjana (D4/S1) adalah sebanyak 172 orang dengan persentase sebesar 70,5\%. Responden dengan pendidikan terakhir tingkat master (S2) adalah sebanyak 27 orang dengan persentase sebesar 11,1\%. Terakhir, responden dengan pendidikan terakhir tingkat doktor (S3) adalah sebanyak satu orang dengan persentase sebesar $0,4 \%$.

Jumlah responden yang berprofesi sebagai ibu rumah tangga adalah sebanyak 11 orang dengan persentase sebesar 4,5\%. Jumlah responden yang berprofesi sebagai wirausaha adalah sebanyak 46 orang dengan persentase sebesar 18,9\%. Jumlah responden yang bekerja sebagai karyawan swasta/BUMN adalah sebanyak 153 orang dengan persentase sebesar $62,7 \%$. Responden yang berprofesi sebagai pegawai negeri sipil (PNS) adalah sebanyak 8 orang dengan persentase sebesar $3,3 \%$. Berbeda tipis dengan PNS, responden yang bekerja sebagai professional adalah sebanyak 9 orang dengan persentase sebesar 3,7\%. Terakhir, responden dengan kategori pekerjaan lainnya adalah sebanyak 17 orang dengan persentase sebesar $7 \%$.

Jumlah responden dengan penghasilan $<5$ juta rupiah adalah sebanyak 65 orang dengan persentase sebesar 26,6\%. Jumlah responden 
dengan penghasilan Rp 5.000.001-10.000.000 sebanyak 116 orang dengan persentase sebesar 47,5\%. Selanjutnya, jumlah responden dengan penghasilan Rp 10.000.001-15.000.000 sebanyak 34 orang dengan persentase sebesar 13,9\%. Jumlah responden dengan penghasilan $\mathrm{Rp}$ 15.000.001-20.000.000 sebanyak 20 orang dengan persentase sebesar $8,2 \%$. Terakhir, jumlah responden dengan penghasilan $>20$ juta rupiah adalah sebanyak 9 orang dengan persentase sebesar 3,7\%.

Pengujian hipotesis menggunakan regresi linier berganda bertujuan untuk membuktikan hipotesis pada penelitian ini yaitu attitude, subjective norms, price, location, dan developer's reputation secara bersama-sama memiliki pengaruh secara signifikan terhadap purchase intention konsumen pada apartemen di Sidoarjo. Adapun hasil uji regresi linier berganda yang telah dilakukan dapat dilihat pada tabel berikut. 1. Nilai unstandar koefisien atau koefisien konstanta 0,225 menunjukkan bahwa apabila nilai dari $\mathrm{X} 1, \mathrm{X} 2, \mathrm{X} 3, \mathrm{X} 4$, dan $\mathrm{X} 5$ sama dengan 0 , maka tingkat atau besarnya variabel dependen Y akan sebesar 0,225.

2. Nilai Adjusted R Square yang diperoleh adalah sebesar 0,526 yang menunjukkan bahwa terdapat hubungan yang bersifat pengaruh antara variabel independen (attitude, subjective norms, price, location, and developer's reputation) terhadap variabel dependen (purchase intention) yakni sebesar 52,6\%. Sedangkan sisanya sebesar $47,4 \%$ dijelaskan oleh faktorfaktor lain yang tidak masuk dalam model regresi penelitian ini.

3. Melihat nilai correlation partial pada Tabel 1 dapat disimpulkan bahwa urutan variabel independen yang memiliki pengaruh paling besar terhadap variabel dependen (purchase intention) adalah attitude (0,279), subjective norms $(0,191)$, location $(0,169)$, developer's reputation $(0,134)$, dan price $(0,132)$.

4. Variabel attitude menunjukkan tingkat signifikansi 0,000 yang berarti nilainya lebih kecil

Tabel 1 Hasil Regresi Linier Berganda

\begin{tabular}{|l|c|c|c|c|c|c|}
\hline \multicolumn{1}{|c|}{ Variabel } & Sig. & Nilai t & $\begin{array}{c}\text { Unstandart } \\
\text { Koe fisien }\end{array}$ & $\begin{array}{c}\text { Correlation } \\
\text { Partial }\end{array}$ & $\begin{array}{c}\text { Model } \\
\text { Summary }\end{array}$ & Kete rangan \\
\hline Constant & & & 0,225 & & & \\
\hline Adjusted R Square & & & & & 0,526 & Signifikan \\
\hline $\begin{array}{l}\text { H1: Attitude (X1) } \rightarrow \text { Purchase } \\
\text { Intention (Y) }\end{array}$ & 0,000 & 4,478 & 0,328 & 0,279 & & Signifikan \\
\hline $\begin{array}{l}\text { H2: Subjective Norms (X2) } \rightarrow \\
\text { Purchase Intention (Y) }\end{array}$ & 0,003 & 3,005 & 0,160 & 0,191 & & Signifikan \\
\hline $\begin{array}{l}\text { H3: Price (X3) } \rightarrow \text { Purchase } \\
\text { Intention (Y) }\end{array}$ & 0,041 & 2,056 & 0,126 & 0,132 & & Signifikan \\
\hline $\begin{array}{l}\text { H4: Location (X4) } \rightarrow \text { Purchase } \\
\text { Intention (Y) }\end{array}$ & 0,009 & 2,640 & 0,178 & 0,169 & & Signifikan \\
\hline $\begin{array}{l}\text { H5: Developer's Reputation } \\
\text { X5) } \rightarrow \text { Purchase Intention (Y) }\end{array}$ & 0,038 & 2,091 & 0,133 & 0,134 & & \\
\hline
\end{tabular}

Sumber: Lampiran 5 
daripada 0,05 . Nilai t positif sebesar 4,478 menunjukkan bahwa variabel attitude memiliki hubungan yang searah dengan variabel purchase intention. Harga koefisien b1 = 0,328 mengartikan bahwa apabila nilai variabel attitude (X1) mengalami kenaikan sebesar satu poin, sementara variabel independen lainnya bersifat tetap, maka tingkat variabel purchase intention $(\mathrm{Y})$ akan meningkat sebesar 0,328. Berdasarkan hasil data tersebut dapat disimpulkan bahwa sikap konsumen terhadap apartemen di Sidoarjo memiliki pengaruh yang signifikan terhadap niat beli mereka. Pengaruh tersebut memiliki arah yang positif, artinya apabila semakin baik sikap konsumen terhadap apartemen di Sidoarjo, maka semakin tinggi pula niat beli pada konsumen. Berdasarkan analisis tersebut maka hipotesis penelitian satu (H1) diterima.

5. Variabel subjective norms menunjukkan tingkat signifikansi 0,003 yang berarti nilainya lebih kecil daripada 0,05 . Nilai $t$ positif sebesar 3,005 menunjukkan bahwa variabel subjective norms memiliki hubungan yang searah dengan variabel purchase intention. Harga koefisien b2 $=0,160$, berarti bahwa apabila nilai variabel subjective norms (X2) mengalami kenaikan sebesar satu poin, sementara variabel independen lainnya bersifat tetap, maka tingkat variabel purchase intention (Y) akan meningkat sebesar 0,160. Berdasarkan hasil data tersebut dapat disimpulkan bahwa norma subjektif memiliki pengaruh yang signifikan terhadap niat beli pada konsumen. Pengaruh tersebut memiliki arah yang positif, artinya apabila norma subjektif konsumen semakin tinggi maka akan semakin tinggi juga niat beli yang dimiliki oleh konsumen. Berdasarkan analisis tersebut maka hipotesis penelitian dua (H2) diterima.
6. Variabel price menunjukkan tingkat signifikansi 0,041 yang berarti nilainya lebih kecil daripada 0,05. Nilai t positif sebesar 2,056 menunjukkan bahwa variabel price memiliki hubungan yang searah dengan variabel purchase intention. Harga koefisien b3 $=0,126$, berarti bahwa apabila nilai variabel price (X3) mengalami kenaikan sebesar satu poin, sementara variabel independen lainnya bersifat tetap, maka tingkat variabel purchase intention (Y) akan meningkat sebesar 0,126. Berdasarkan hasil data tersebut dapat disimpulkan bahwa harga apartemen di Sidoarjo memiliki pengaruh yang signifikan terhadap niat beli konsumen. Pengaruh tersebut memiliki arah yang positif, artinya apabila semakin baik harga apartemen di Sidoarjo maka akan semakin tinggi juga niat beli pada konsumen. Berdasarkan analisis tersebut maka hipotesis penelitian tiga $(\mathrm{H} 3)$ diterima.

7. Variabel location menunjukkan tingkat signifikansi 0,009 yang berarti nilainya lebih kecil daripada 0,05. Nilai t positif sebesar 2,640 menunjukkan bahwa variabel location memiliki hubungan yang searah dengan variabel purchase intention. Harga koefisien b4 = 0,178 , berarti bahwa apabila nilai variabel location (X4) mengalami kenaikan sebesar satu poin, sementara variabel independen lainnya bersifat tetap maka tingkat variabel purchase intention (Y) akan meningkat sebesar 0,178. Berdasarkan hasil data tersebut dapat disimpulkan bahwa lokasi memiliki pengaruh yang signifikan terhadap niat beli konsumen pada apartemen di Sidoarjo. Pengaruh tersebut memiliki arah yang positif, artinya apabila semakin baik lokasi yang dimiliki oleh apartemen di Sidoarjo maka semakin tinggi pula niat beli pada konsumen. Berdasarkan analisis tersebut maka hipotesis penelitian empat (H4) diterima. 
8. Variabel developer's reputation menunjukkan tingkat signifikansi 0,038 yang berarti nilainya lebih kecil daripada 0,05. Nilai $t$ positif sebesar 2,091 menunjukkan bahwa variabel developer's reputation memiliki hubungan yang searah dengan variabel purchase intention. Harga koefisien b5 $=0,133$, berarti bahwa apabila nilai variabel developer's reputation (X5) mengalami kenaikan sebesar satu poin, sementara variabel independen lainnya bersifat tetap, maka tingkat variabel purchase intention $(\mathrm{Y})$ akan meningkat sebesar 0,133. Berdasarkan hasil data tersebut dapat disimpulkan bahwa reputasi yang dimiliki oleh developer memiliki pengaruh yang signifikan terhadap niat beli konsumen apartemen di Sidoarjo. Pengaruh tersebut memiliki arah yang positif, artinya apabila semakin baik reputasi yang dimiliki oleh suatu developer maka akan semakin tinggi juga niat beli pada konsumen. Berdasarkan analisis tersebut maka hipotesis penelitian lima (H5) diterima.

\section{DISKUSI}

Attitude Terhadap Apartemen di Sidoarjo dan Purchase Intention

Berdasarkan hasil pengolahan data dan uji hipotesis yang telah dilakukan sebelumnya, diperoleh hasil bahwa terdapat pengaruh yang signifikan dan positif antara attitude terhadap apartemen di Sidoarjo dan purchase intention. Ketika konsumen memiliki keyakinan yang kuat bahwa membeli apartemen di Sidoarjo adalah sebuah keputusan yang menguntungkan maka akan semakin meningkatkan niat beli konsumen. Hal ini digambarkan oleh indicator AT-4 dengan pernyataan "Saya merasa membeli apartemen di Sidoarjo adalah keputusan yang menguntungkan" memiliki nilai tertinggi.
Attitude atau sikap didefinisikan sebagai kecenderungan psikologis yang diekspresikan dengan mengevaluasi entitas tertentu dengan beberapa tingkat suka atau tidak suka (Ajzen \& Fishbein, 1980). Attitude adalah kesukaan atau ketidaksukaan seseorang terhadap suatu behavior (Al-Nahdi, dkk., 2014:39). Attitude juga didefinisikan sebagai cara individu merespons dan cenderung terhadap suatu objek (Yusliza dan Ramayah, 2011:491). Studi sebelumnya oleh Kim dan Han (2010:1000) menemukan bahwa terdapat hubungan yang kuat dan stabil antara attitude dan purchase intention.

\section{Subjective Norms dan Purchase Intention}

Berdasarkan hasil pengolahan data dan uji hipotesis yang telah dilakukan sebelumnya, diperoleh hasil bahwa terdapat pengaruh yang signifikan dan positif antara subjective norms dan purchase intention. Temuan dalam penelitian ini dapat menggambarkan bahwa konsumen berminat membeli apartemen di Sidoarjo karena melihat banyaknya online review yang positif mengenai apartemen di Sidoarjo. Artinya, ketika konsumen menemukan banyak ulasan positif di internet yang membahas tentang apartemen di Sidoarjo maka akan semakin meningkatkan niat beli mereka. Hal ini dapat digambarkan oleh indikator SN-4 dengan pernyataan "Saya berminat membeli apartemen di Sidoarjo karena melihat banyak online review yang positif" memiliki nilai tertinggi.

Temuan tersebut sangat sesuai dengan karakteristik responden yang mayoritas berusia antara 26-30 yang cukup familiar dengan teknologi dan internet dalam kehidupan sehariharinya. Subjective norms merupakan hasil dari bagaimana seseorang merasakan tekanan yang diberikan oleh orang lain untuk melakukan atau 
tidak melakukan suatu perilaku (Ajzen, 1991). Kokliè \& Vida (2009) dalam Al-Nahdi (2014:33) menyebutkan bahwa faktor eksternal konsumen, seperti kelompok referensi atau keluarga dapat memengaruhi proses pembelian rumah. Susilawati dkk., (2001:5) menemukan dalam penelitiannya bahwa sebesar $45 \%$ pengambilan keputusan untuk membeli hunian dipengaruhi oleh kolega, teman, dan istri. Adapun faktor sosial dan budaya juga memainkan peran penting dalam menunjukkan preferensi perumahan yang ditentukan oleh agama, kekerabatan, dan hubungan sosial (Jabareen, 2005:143). Hal tersebut mencerminkan bahwa faktor sosial memainkan peranan penting dalam memengaruhi niat pembelian.

\section{Price dan Purchase Intention}

Berdasarkan hasil pengolahan data yang dilakukan diperoleh hasil bahwa terdapat pengaruh signifikan antara price terhadap purchase intention. Tingkat harga merupakan pertimbangan utama bagi konsumen selama proses pembelian. Harga apartemen yang sesuai dengan kemampuan finansial konsumen akan semakin meningkatkan niat beli mereka. Hal tersebut dapat dicerminkan oleh indikator P-1 di mana mayoritas responden setuju bahwa mereka berminat untuk membeli apartemen di Sidoarjo dengan harga yang sesuai dengan kemampuan finansial mereka.

Temuan tersebut dapat dikaitkan dengan karakteristik mayoritas responden yang berpenghasilan antara 5-10 juta rupiah dan berprofesi sebagai karyawan swasta/BUMN. Hal ini membuat konsumen menjadi lebih pemilih dalam memilih apartemen dengan budget yang sesuai dengan kemampuan mereka. Dengan kemudahan akses internet atau komunikasi dari mulut ke mulut, konsumen dapat membandingkan harga di antara produk yang sama sebelum membuat keputusan pembelian (Tsou, dkk., 2015:4). Sejalan dengan hal tersebut, penelitian milik Nasar dan Manoj (2014:8) mencatat bahwa harga apartemen adalah menduduki peringkat tertinggi sebagai faktor yang paling signifikan memengaruhi purchase decision konsumen.

\section{Location dan Purchase Intention}

Berdasarkan hasil pengolahan data yang dilakukan diperoleh hasil bahwa terdapat pengaruh signifikan antara location terhadap purchase intention. Lokasi apartemen adalah salah satu faktor yang memengaruhi niat beli individu untuk membeli apartemen. Hal tersebut dicerminkan oleh indikator L-3 dan L-4 bahwa ketika apartemen di Sidoarjo memiliki lokasi yang dekat dengan pusat entertainment seperti pusat perbelanjaan, bisokop, restaurant/café, serta dekat dengan pelayanan umum seperti rumah sakit dan kantor pemerintahan maka akan semakin meningkatkan niat beli konsumen.

Apartemen yang berlokasi dekat dengan pusat entertainment atau pusat pelayanan umum dapat memberikan kepraktisan kepada para penghuninya. Kepraktisan gaya hidup sangat sesuai dengan karakteristik mayoritas penduduk Indonesia yang didominasi oleh milenial, di mana mereka lebih memprioritaskan rumah layak huni dan berkualitas berupa apartemen atau hunian di pusat kota yang terintegrasi dengan simpul transportasi umum dan memiliki kemudahan dalam akses internet (Jannah, 2019). Hal tersebut sangat sesuai dengan karakteristik responden yang mayoritas adalah penduduk yang berdomisili di perkotaan (Surabaya) dengan usia antara 26-30 tahun. 


\section{Developer's Reputation dan Purchase Intention}

Developer's reputation memiliki pengaruh yang signifikan terhadap purchase intention. Hal ini mengindikasikan bahwa reputasi developer menurut konsumen menjadi pengaruh terhadap keputusan pembelian mereka. Ketika reputasi developer berkompeten dalam pembangunan apartemen, maka akan semakin meningkatkan konsumen untuk membeli apartemen di Sidoarjo. Hal tersebut dicerminkan pada indikator DR-3 dengan pernyataan "Saya berminat membeli apartemen di Sidoarjo yang dibangun oleh developer berkompetensi di bidang pembangunan apartemen", memiliki nilai tertinggi. Hal tersebut saling berkaitan sebab reputasi yang kuat meningkatkan kepercayaan konsumen terhadap produk dan layanan yang ditawarkan sehingga berpengaruh pada niat pembelian konsumen.

Menurut penelitian yang dilakukan oleh Nassar dan Manoj (2014:8) reputasi yang dimiliki oleh developer menjadi faktor pendorong seseorang melakukan pembelian apartemen. Karena reputasi memiliki kaitan erat dengan kepercayaan konsumen terhadap perusahaan pengembang. Semakin bagus reputasi yang dimiliki oleh developer maka semakin tinggi pengaruhnya terhadap purchase intention. Umumnya, konsumen lebih peduli tentang reputasi karena citra dan reputasi suatu merek dapat membantu mereka menyimpulkan kualitas produk (Tsou, dkk., 2015:14).

\section{KESIMPULAN}

Berdasarkan hasil analisis dan pembahasan yang telah dijelaskan pada bab sebelumnya, penulis memperoleh kesimpulan yang dapat diambil dari penelitian "Analisis Theory of Reasoned Action serta Pengaruh Price, Location, dan Developer's Reputation terhadap Purchase
Intention pada Apartemen di Sidoarjo", yaitu sebagai berikut: Attitude terhadap apartemen di Sidoarjo memiliki pengaruh positif dan signifikan terhadap purchase intention. Attitude konsumen terhadap apartemen di Sidoarjo memiliki pengaruh yang paling besar di antara faktor lainnya dalam memengaruhi purchase intention. Subjective norms memiliki pengaruh positif dan signifikan terhadap purchase intention. Price memiliki pengaruh positif dan signifikan terhadap purchase intention. Location memiliki pengaruh positif dan signifikan terhadap purchase intention. Developer's reputation memiliki pengaruh positif dan signifikan terhadap purchase intention.

Sebagai suatu penelitian maka kesimpulan yang ditarik tentu mempunyai suatu implikasi. Dalam studi ini terdapat dua implikasi yang dapat dirasakan oleh pihak akademisi dan perusahaan. Penjelasan mengenai kedua implikasi tersebut akan dijabarkan sebagai berikut. Hasil penelitian ini menunjukkan bahwa theory of reasoned action relevan digunakan dalam memprediksi niat beli konsumen terhadap apartemen di Sidoarjo. Selain itu, studi ini juga mengimplikasikan bahwa harga apartemen, lokasi apartemen serta reputasi pengembang juga dapat memberikan pengaruh yang signifikan dan positif pada niat beli konsumen. Sikap terhadap apartemen di Sidoarjo yang dimiliki oleh konsumen mempunyai pengaruh paling besar terhadap niat beli mereka. Kemudian disusul dengan norma subjektif, lokasi apartemen, reputasi developer, dan yang terakhir adalah harga apartemen sehingga hasil penelitian ini dapat dikembangkan dengan memperhatikan faktor-faktor lain yang belum pernah diteliti pada studi sebelumnya.

Temuan dalam studi ini menggambarkan bahwa attitude terhadap apartemen di Sidoarjo memiliki pengaruh yang paling besar di antara 
faktor lainnya dalam memengaruhi purchase intention konsumen. Strategi yang dapat diterapkan oleh para developer apartemen di Sidoarjo adalah menekankan kepada konsumen bahwa membeli apartemen di Sidoarjo merupakan ide yang bagus dan sebuah keputusan menguntungkan. Melalui kegiatan personal selling hal tersebut dapat dilakukan dengan menyediakan sales person yang professional dan terlatih untuk menyediakan informasi sebanyak mungkin, termasuk mengedukasi para pembeli potensial dengan menjelaskan proyeksi kenaikan harga apartemen di masa depan.

Selain itu, mengingat sebagian responden dalam penelitian ini adalah golongan milenial, perusahaan dapat memanfaatkan influencer dalam menggiring dan membentuk opini publik. Penelitian ini juga menggambarkan bahwa konsumen berminat membeli apartemen di Sidoarjo ketika melihat banyaknya online review yang positif mengenai apartemen di Sidoarjo. Artinya, ketika konsumen menemukan banyak ulasan positif di internet yang membahas tentang apartemen di Sidoarjo maka akan semakin meningkatkan niat beli mereka. Oleh karena itu, peran influencer dalam hal ini dapat digunakan untuk meningkatkan niat beli konsumen pada apartemen di Sidoaro.

\section{DAFTAR RUJUKAN}

Al-Nahdi, T.S. 2014. Factors Influencing The Intention to Purchase Real Estate in Saudi Arabia: Role of Location. Journal of Applied Science and Agriculture, Vol. 9(18), 32-42.

Chia, J., Harun, A., Kassim, AWM., Martin, D., \& Kepal, N. 2016. Understanding Factors that Influence House Purchase
Intention among Consumer in Kota Kinabalu: An Application of Buyer Behavior Model Theory. Journal of Technology Management and Business, Vol. 3(2), 94110.

Ginanjar, D. 2019. Sidoarjo Makin Memikat Jadi Tempat Tinggal, Rumah Murah Susah Dicari. Jawa Pos. Diakses melalui website https://www.jawapos.com/surabaya/19/08/ 2019/sidoarjo-makin-memikat-jadi-tempattinggal-rumah-murah-susah-dicari/ pada Minggu, 01 September 2019.

Jabareen, Y. 2005. Culture and Housing Preferences in A Developing City. Journal of Environment and Behavior, Vol. 37(1): 134-146.

Jannah, S.M. 2019. 81 Juta Generasi Milenial Tak Punya Rumah, PUPR Rancang KPR Khusus. Tirto.id. Diakses melalui website https:/ /tirto.id/81-juta-generasi-milenial-tak-punya-rumah-pupr-rancang-kpr-khusus-ecFe pada Kamis, 01 September 2019.

Kamal, M. \& Pramanik, S.A.K. 2015. Customers' Intention towards Purchasing Apartment in Dhaka City, Bangladesh: Offering an Alternative Buying Intention Model. European Journal of Business and Management, Vol. 7(35), 45-58.

Karya, D.F., Katias, P., \& Herlambang, T. 2018. Stock Price Estimation Using Ensemble Kalman Filter Square Root Method. Journal of Physics: Conference Series, 1008 (1), 012017.

Kaynak, E., \& Stevenson. 1982. Comparative Study of Home Buying Behaviour of Atlantic Canadians. Management Research News, Vol. 5(1), 3-11.

Kim, Y. \& Han, H. (2010). Intention to Pay Conventional-Hotel Prices at a Green Hotel: A Modification of the Theory of 
Planned Behavior. Journal of Sustainable Tourism, Vol. 18(8), 997-1014.

Mollah, M.M.H., Haque, I., \& Pasha, S.H.A. (2009). Factors Influencing Apartment Buying Decision: An Analysis of Company and Customer Perspective. Southeast University Journal of Business Studies, Vol. 5(2), 109-121.

Nasar, K.K., \& Manoj, P.K. 2014. Factors Influencing the Purchase of Apartments: Some Empirical Evidence. Clear International Journal of Research in Management, Science and Technology, Vol. 4(8), 1-11.

Nursal, A.T., Omar, M.F., Nawi, M.N., \& Sapri, M.M. 2019. The Importance of Developer Reputation Criterion in House Purchase Decision Making. International Journal of Supply Chain Management, Vol. 8(1), 697-701.

Onggo, Y., Setiawan, A., Arifianthie, R.V., \& Rizal, S. 2018. Faktor yang Menentukan Keputusan Membeli Apartemen. Journal of Indonesian Business Review, Vol. 1(1), 94-103.

Opoku, R. \& Abdul-Muhmin, A.G. 2010. Housing Preferences and Attribute Importance among Low-Income Consumers in Saudi Arabia. Habitat International, Vol. 34, 219-227.
Razak, I., Ibrahim, R., Hoo, J., Osman, I., \& Alias, Z. 2013. Purchasing Intention towards Real Estate Development in Setia Alam, Shah Alam: Evidence from Malaysia. International Journal of Business, Humanities and Technology, Vol. 3(6), 66-75.

Sangkakoon, P., Ngarmyarn, A., \& Panichpathom, S. 2014. The Influence of Group References in Home Purchase Intention in Thailand. 21st Annual European Real Estate Society Conference. ERES: Conference. Bucharest, Romania, 2014.

Tsou, H.T., Liu, F.H., \& Hsu, H.Y. 2015. The Effects of Reputation and Relative Low Price on Purchase Intention: Service Quality as a Mediated Moderator. Journal of Chinese Management Review, Vol. 18(3): 1-16.

Wu, KS., \& Teng, YM. 2011. Applying the Extended Theory of Planned Behavior to Predict The Intention of Visiting A Green Hotel. African Journal of Business Management, Vol. 5(17): 7579-7587.

Yusliza, MY. \& Ramayah, T. 2011. Explaining the Intention to Use Electronic HRM among HR Professionals: Results from a Pilot Study. Australian Journal of Basic and Applied Sciences, Vol. 5(8): 489-497. 